\title{
A note on congenital abnormalities of the penis Incidence and relationship to urethritis
}

\author{
A. I. MORRISON \\ Special Treatment Centre, Queens Road, Barnsley, Yorks.
}

Minor structural abnormalities of the penis are of frequent occurrence, and most commonly involve the urethra.

Venereal disease clinics afford exceptional opportunities for observing such abnormalities, and also provide a group of patients by which the degree of biased selection can be assessed in that at least half of those attending do not suffer from infections of the urethra. This paper presents an account of the incidence and clinical associations of structural abnormalities of the penis seen in one clinic in the course of 19 years.

Epispadias, in which the urethral orifice is situated on the dorsal surface of the penis, and which is extremely rare, may be glandular, penile, or complete.

Hypospadias, in which the urethral orifice is situated on the ventral surface of the penis at any point on the midline from the glans to the perineum, is the abnormality most frequently found. McCrea $(1940$, p. 45$)$ stated that an hereditary element was associated with this abnormality which could occur together with other penile or scrotal malformations. Nové-Josserand (1922) described four types of this condition, but did not mention intrameatal hypospadias; this was first described by Harkness (1948). Harkness (1950) stressed (with excellent illustrations of cases) that it could be found only by everting the lips of the external urinary meatus.

Meatal, or paraurethral canals or ducts, are small mucous canals which open into the meatus or on to the glans, but usually end blindly and are frequently rssociated with hypospadias (McCrea, 1940, p. 38). They have been studied by Churchman (1906).

Received for publication January 28, 1970
Longer ducts may be referred to as accessory urethral canals; they may be situated either dorsal or ventral to the normal urethra. Most of them end blindly but rarely there may be communication with the urethra. They have been discussed by Harkness (1950, p. 332) and also by McCrea (1940, p. 36), who mentioned the studies of de Berne-Lagarde (1932), Chauvin (1927), and Le Fort (1896). Ventral accessory ducts were studied by Lévy and Planson (1914) and Oudard and Jean (1921).

Phimosis may be congenital or inflammatory; cases of the former are unlikely to be seen in adults because the condition will often have been corrected in childhood by circumcision.

\section{Case material}

From November, 1950, to December, 1969, a total of 2,407 men attending the clinic was examined for congenital penile abnormalities as well as undergoing the routine examinations. The patients were all white, and their ages ranged from 12 to 80 years (average 30.9). During the 19-year period of the survey, these 2,407 men contributed 2,874 diagnoses (Table $\mathrm{I}$ ).

TABLE I Conditions diagnosed

\begin{tabular}{lr}
\hline Syphilis & 61 \\
Gonorrhoea & 587 \\
Nongonococcal urethritis & 542 \\
Chancroid & 3 \\
Lymphogranuloma venereum & 1 \\
All other conditions & 1,680 \\
\hline Total & 2,874 \\
\hline
\end{tabular}

There were 463 cases of urethral re-infection or concurrence of other conditions, and four cases of double infection with syphilis and gonorrhoea.

TABLE II Clinical associations of minor congenital abnormalities of the penis. 167 cases in 164 patients

\begin{tabular}{|c|c|c|c|c|}
\hline \multirow[b]{2}{*}{ Abnormality } & \multicolumn{4}{|c|}{ Clinical diagnosis } \\
\hline & Gonorrhoea & Nongonococcal urethritis & Other conditions & Total \\
\hline $\begin{array}{l}\text { Hypospadias } \\
\text { Meatal hypospadias } \\
\text { Intrameatal hypospadias } \\
\text { Meatal and intrameatal hypospadias } \\
\text { Accessory urethral ducts }\end{array}$ & $\begin{array}{r}15 \\
28 \\
10 \\
0 \\
0\end{array}$ & $\begin{array}{r}5 \\
22 \\
9 \\
4 \\
0\end{array}$ & $\begin{array}{r}17 \\
31 \\
24 \\
0 \\
2\end{array}$ & $\begin{array}{r}37 \\
81 \\
43 \\
4 \\
2\end{array}$ \\
\hline Total & 53 & 40 & 74 & 167 \\
\hline
\end{tabular}


Results (Table II)

Among the 2,407 men, there were 164 with minor congenital abnormalities of the penis, an incidence of 6.8 per cent. Of the 164 patients, 74 ( $45 \cdot 1$ per cent.) had disorders other than infections of the urethra; 90 (54.9 per cent.) suffered either gonorrhoea or nongonococcal urethritis. In both the 'urethritis' and 'non-urethritis' groups, meatal hypospadias was the most frequent abnormality and the next most frequent was intrameatal hypospadias. Expressing the figures as cases and not as individual patients, among 587 infections with gonorrhoea there were 53 (9.0 per cent.) instances of minor congenital abnormality of the penis, 28 of them meatal hypospadias. Among 542 infections with nongonococcal urethritis, the corresponding figures were $40(7 \cdot 4 \mathrm{per}$ cent.) and 22. Harkness (1950) found the incidence of hypospadias in cases of gonococcal and nongonococcal urethritis to be 1 in 25 . He considered that the stratified squamous epithelium of the normal fossa navicularis acted in some way as a barrier to urethral infection; he stated that in his experience infection was more frequent when this barrier was absent, as in hypospadias. Clinical proof of this theory would obviously be impossible because one cannot examine all the sexual partners in all 'urethritis' and 'non-urethritis' cases. In the present series there were 1,129 cases of urethritis and 1,745 with no urethritis; the incidence of all types of hypospadias in the former group was 8.2 per cent. and in the latter it was $4 \cdot 1$ per cent. Conversely, of 165 cases of all types of hypospadias, $93(56.4$ per cent.) were associated with urethritis and 72 (43.6 per cent.) with other conditions. These findings give at least indirect support to Harkness's contention.

\section{Discussion}

In this series there were surprisingly only two cases of paraurethral duct without associated hypospadias. In one patient the duct was situated on the left side of the penis and in the other an infected accessory duct was situated on the ventral aspect of the penis with an abscess at the base; this had been noticed as a swelling since childhood, and had been described as a cyst. A concretion was found on incision. The fraenum was not attached to the penis and the urinary meatus was very small, probably because of congenital stricture. In both cases the duct ended blindly. Harkness (1950, p. 332) stated that in rare cases long accessory urethral canals might communicate with the membranous or bulbous urethra, or even with the bladder, seminal vesicles, or ejaculatory ducts.
Phimosis was found only in association with infection and no case of undoubted congenital phimosis was seen. There was no case of epispadias.

\section{Summary}

164 cases of minor congenital abnormality of the penis were found among 2,407 men attending a venereal diseases clinic, an incidence of 6.8 per cent. Meatal hypospadias was the most frequent finding. The incidence of all types of hypospadias in 1,129 cases of gonococcal and nongonococcal urethritis was 8.2 per cent.; it was 4.1 per cent. in 1,745 cases without urethritis. Conversely, 56.4 per cent. of cases of hypospadias were seen in association with urethral infections, whereas 43.6 per cent. were associated with other conditions. These findings lend indirect support to the contention that hypospadias lessens the minor protection against infection afforded by the normal fossa navicularis.

\section{References}

Chauvin, E. (1927) F. Urol. (Paris), 23, 289

Churchman, J. W. (1906) fohns Hopk. Hosp. Rep. 13, 101

De BeRNe-LAGARDe (1932) Arch. Mal. Reins. Org. gén.-urin 7, 39

HARKNESS, A. H. (1948) Brit. F. vener. Dis., 24, 137

- (1950) 'Non-gonococcal Urethritis', pp. 329-335. Livingstone, Edinburgh

Le FORT, R. (1896) Ann. Mal. Org. gén.-urin., 14, 624, 694, 792, 912, 1095.

LÉvy, F., and Planson, V. (1914) F. Urol. (Paris), 5,419

McCrea, E. D. (1940) 'Diseases of the Urethra and Penis', pp. 25-48. Wright, Bristol

Noví-JosserAND, G. (1922) 'Abouchements anormaux et fistules congénitales de l'urètre', in 'Encyclopédie française d'urologie', ed. A. Pousson and E. Desnos, vol. 5, p. 858. Doin, Paris

Oudard and Jean, G. (1921) f. Urol. (Paris), 11, 177

\section{Anomalies congénitales de la verge}

SOMMAIRE

164 cas d'anomalies congénitales mineures de la verge furent trouvés chez 2.407 consultants d'une clinique vénéréologique, soit 6,8 pour cent. La constatation la plus fréquente fut l'hypospadias du méat. L'incidence de tout type d'hypospadias fut de 8,2 pour cent des malades atteints de gonococcie ou d'urétrite non gonococcique; elle fut de 4,1 pour cent pour 1.745 cas sans urétrite. Ainsi, 56,4 pour cent des cas d'hypospadias furent rencontrés associés à des infections urétrales alors que 43,6 pour cent étaient rencontrés dans d'autres conditions. Ces résultats tendent à supporter indirectement l'opinion que l'hypospadias diminue la protection mineure qu'une fosse naviculaire normale apporte à l'infection. 